Article

\title{
Evaluation of FAO-56 Procedures for Estimating Reference Evapotranspiration Using Missing Climatic Data for a Brazilian Tropical Savanna
}

\author{
Luiz Claudio Galvão do Valle Júnior ${ }^{1}\left(\mathbb{D}\right.$, George L. Vourlitis ${ }^{2}$, Leone Francisco Amorim Curado ${ }^{3}$, \\ Rafael da Silva Palácios ${ }^{4}$, José de S. Nogueira ${ }^{3}\left({ }^{\circ}\right.$, Francisco de A. Lobo ${ }^{5}$, Abu Reza Md Towfiqul Islam ${ }^{6}(\mathbb{D}$ \\ and Thiago Rangel Rodrigues $7, *$ (i)
}

check for

updates

Citation: Valle Júnior, L.C.G.d.; Vourlitis, G.L.; Curado, L.F.A.;

Palácios, R.d.S.; Nogueira, J.d.S.;

Lobo, F.d.A.; Islam, A.R.M.T.;

Rodrigues, T.R. Evaluation of FAO-56

Procedures for Estimating Reference Evapotranspiration Using Missing Climatic Data for a Brazilian Tropical Savanna. Water 2021, 13, 1763.

https://doi.org/10.3390/w13131763

Academic Editor: Antonio Lo Porto

Received: 22 May 2021

Accepted: 20 June 2021

Published: 26 June 2021

Publisher's Note: MDPI stays neutral with regard to jurisdictional claims in published maps and institutional affiliations.

Copyright: (c) 2021 by the authors. Licensee MDPI, Basel, Switzerland. This article is an open access article distributed under the terms and conditions of the Creative Commons Attribution (CC BY) license (https:// creativecommons.org/licenses/by/ $4.0 /)$.
1 Programa de Pós-Graduação Tecnologias Ambientais, Universidade Federal de Mato Grosso do Sul, Campo Grande 79070-900, Brazil; luizvallejr@gmail.com

2 Biological Sciences Department, California State University, San Marcos, CA 92096, USA; georgev@csusm.edu

3 Programa de Pós Graduação em Física Ambiental, Instituto de Física, Universidade Federal de Mato Grosso, Cuiabá 78060-900, Brazil; leonecurado@gmail.com (L.F.A.C.); nogueira@ufmt.br (J.d.S.N.)

4 Faculdade de Meteorologia, Instituto de Geociências, Universidade Federal do Pará, Belém 66075-110, Brazil; rafael.pgfa@gmail.com

5 Departamento de Solos e Engenharia Rural, Faculdade de Agronomia e Zootecnia, Universidade Federal de Mato Grosso, Cuiabá 78060-900, Brazil; fdealobo@gmail.com

6 Department of Disaster Management, Begum Rokeya University, Rangpur 5400, Bangladesh; towfiq_dm@brur.ac.bd

7 Laboratório de Ciências Atmosféricas, Universidade Federal de Mato Grosso do Sul, Campo Grande 79070-900, Brazil

* Correspondence: thiago.r.rodrigues@ufms.br

\begin{abstract}
The Brazilian savanna (Cerrado) has been heavily impacted by agricultural activities over the last four to five decades, and reliable estimates of reference evapotranspiration $\left(E T_{o}\right)$ are needed for water resource management and irrigation agriculture. The Penman-Monteith (PM) is one of the most accepted models for $E T_{o}$ estimation, but it requires many inputs that are not commonly available. Therefore, assessing the FAO guidelines to compute $E T_{o}$ when meteorological data are missing could lead to a better understanding of which variables are critically important for reliable estimates of $E T_{0}$ and how climatic variables are related to water requirements and atmospheric demands. In this study, $E T_{o}$ was computed for a grass-dominated part of the Cerrado from April 2010 to August 2019. We tested 12 different scenarios considering radiation, relative humidity, and/or wind speed as missing climatic data using guidelines given by the FAO. Our results presented that wind speed and actual vapor pressure do not affect $E T_{o}$ estimates as much as the other climatic variables; therefore, in the Cerrado's conditions, wind speed and relative humidity measurements are less required than temperature and radiation data. When radiation data were missing, the computed $E T_{o}$ was overestimated compared to the benchmark. FAO procedures to estimate the net radiation presented good results during the wet season; however, during the dry season, their results were overestimated because the method could not estimate negative $R_{n}$. Our results indicate that radiation data have the highest impact on $E T_{o}$ for our study area and presumably for regions with similar climatic conditions. In addition, those FAO procedures for estimating radiation are not suitable when radiation data are missing.
\end{abstract}

Keywords: reference evapotranspiration; FAO Penman-Monteith; limited data; Cerrado

\section{Introduction}

Over the last few decades, the hydrological cycle and climate of the Brazilian savanna (locally known as Cerrado) have been heavily affected by human activities, especially by the expansion of irrigation and the replacement of native vegetation by crops [1-6]. Due to 
this irrigated agricultural expansion, it is important to have good management of available water resources. To handle issues involving water requirements and atmospheric demand, the United Nations Food and Agriculture Organization (FAO) recommended calculating crop evapotranspiration $\left(E T_{\mathrm{C}}\right)$ from reference evapotranspiration $\left(E T_{o}\right)$ [7]. Water demands and $\mathrm{ET}_{\mathrm{c}}$ are important considerations to improve water use efficiency in agriculture [8-13].

$E T_{0}$ is the evapotranspiration of a defined hypothetical reference well-watered crop with a crop height of $0.12 \mathrm{~m}$, a canopy resistance of $70 \mathrm{s.m} \mathrm{m}^{-1}$, and an albedo of 0.23 [14]. A "real" $E T_{0}$ value can only be obtained using lysimeters or other precision-measuring devices, which require time and are expensive $[10,15,16]$, however, $E T_{0}$ can be computed from weather data, and climatic parameters are the only factors that affect $E T_{o}$ estimates $[17,18]$. The $E T_{o}$ estimation models available in the literature may be broadly classified as (1) fully physically based combination models that account for mass and energy conservation principles; (2) semi-physically based models that deal with either mass or energy conservation; and (3) black-box models based on artificial neural networks, empirical relationships, and fuzzy and genetic algorithms [19,20]. Several authors [21-24] have reported different methods to compute $E T_{0}$, which have been tested in distinct regions and climates [6,25-29]; however, the Penman-Monteith (PM) method is recommended by the FAO to calculate $E T_{o}$ of any region when the requisite meteorological data are available [17]. The FAO-PM method can be used globally without any regional correction and is well documented and tested, but it has a relatively high data demand $[10,30,31]$.

For daily calculation, FAO-PM method meteorological inputs are the maximum and minimum temperatures, relative air humidity, solar radiation, and wind speed. Allen et al. [17] suggested using the Hargreaves-Samani (HS) method [22] as an alternative when only air temperature data are available. However, the HS method should be verified and compared with the FAO-PM method since it tends to overestimate $E T_{o}$ under high relative humidity conditions and underestimate it under conditions of high wind speed [17,32-34]. FAO also recommends the pan evaporation ( $\left.E_{p a n}\right)$ method, which is related to $E T_{o}$ using an empirically derived pan coefficient $\left(\mathrm{K}_{\mathrm{p}}\right)$ [17].

For many locations around the globe, there is a lack of meteorological data. In Brazil, it is possible to collect climatic data from automatic stations of the National Institute of Meteorology (INMET). Although these data are public and the stations cover a significant part of the Cerrado region, there is neither a measure of net radiation nor estimates of regional solar radiation. Several studies have evaluated the use of FAO-PM method procedures to estimate $E T_{o}$ when solar radiation, wind speed, and relative humidity data are missing [35-41]; however, results vary according to the climatic conditions. Recent studies have used machine learning models to estimate $E T_{o}[6,42-46]$ and $\mathrm{E}_{\mathrm{pan}}$ [47-49] with limited weather data and satellite remote sensing to estimate global and regional real evapotranspiration [20,32], but few studies have reported the effects of meteorological data variability on $E T_{o}$ in the Cerrado, and no studies have addressed the impacts of missing climatic data for estimating $E T_{o}$ in a Brazilian tropical savanna. This research intends to close this gap in the literature.

It is important to evaluate the performance of the procedures and recommendations when $E T_{o}$ is obtained using missing climatic data. Knowing which meteorological data have the highest impact on $E T_{o}$ estimates could guide better investments in measurement instruments and provide a better understanding of the seasonal behavior of weather variables for the Cerrado region. Thus, the prime objective of this study was to assess the guidelines provided by the FAO to estimate $E T_{o}$ when meteorological data are limited for a grass-mixed Cerrado region and discuss the impact of each climatic variable on the $E T_{o}$ estimates. The outcome of this work will help inform water resource managers, irrigation engineers, and other professionals of the possible errors associated with $E T_{0}$ estimates and, thereby, improve water resource management in this vital region. 


\section{Materials and Methods}

\subsection{Study Area}

This study was conducted at the Fazenda Miranda $\left(15^{\circ} 17^{\prime} \mathrm{S}, 56^{\circ} 06^{\prime} \mathrm{W}\right)$, located in the Cuiaba municipality (Figure 1), Brazil. The vegetation is grass-dominated with sparse trees and shrubs, known as a campo sujo or "dirty field" Cerrado [50]. According to the Köppen climate classification, the climate in this area is characterized as Aw, tropical semi-humid, with dry winters and wet summers [51]. The average rainfall is $1420 \mathrm{~mm}$ and the mean annual air temperature is $26.5^{\circ} \mathrm{C}$, with a dry season that extends from May to October $[4,52]$. The study area is on flat terrain at an altitude of $157 \mathrm{~m}$ above sea level.

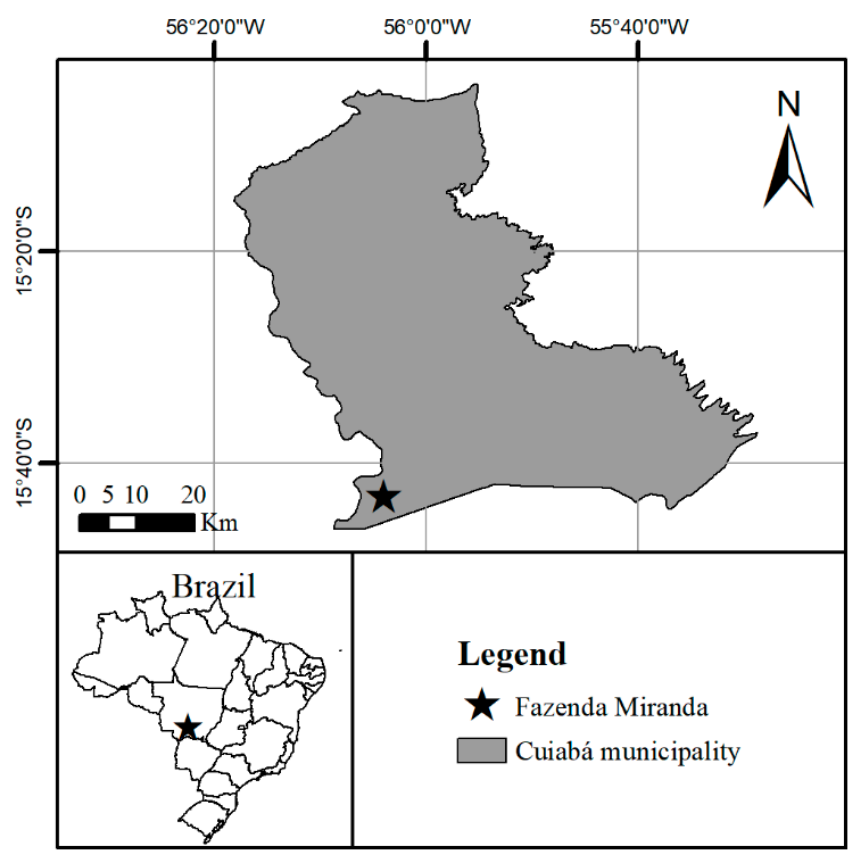

Figure 1. Location of the study site (star) near Cuiabá, Mato Grosso, Brazil.

\subsection{Micrometeorological Measurements}

The measurements were conducted from April 2009 to August 2019. The measurement instruments were installed on a $20 \mathrm{~m}$ tall micrometeorological tower. The data collected were net radiation $\left(R_{n}\right)$, solar radiation $\left(R_{s}\right)$, soil heat flux $(G)$, air temperature $\left(T_{a}\right)$, relative humidity $(R H)$, wind speed $(u)$, soil temperature $\left(T_{\text {soil }}\right)$, soil moisture $(S M)$, and precipitation $(P) . R_{n}$ and $R_{S}$ were measured $5 \mathrm{~m}$ above the ground level using a net radiometer (NR-LITE-L25, Kipp \& Zonen, Delft, The Netherlands) and a pyranometer (LI200X, LI-COR Biosciences, Inc., Lincoln, NE, USA), respectively. $G$ was measured using a heat flux plate (HFP01-L20, Hukseflux Thermal Sensors BV, Delft, The Netherlands) installed $1.0 \mathrm{~cm}$ below the soil surface. SM was measured by a time-domain reflectometry probe (CS616-L50, Campbell Scientific, Inc., Logan, UT, USA) installed $20 \mathrm{~cm}$ below the soil surface. $T_{\text {soil }}$ was measured by a temperature probe (108 Temperature Probe, Campbell Scientific, Inc., Logan, UT, USA) installed $1 \mathrm{~cm}$ below the ground level. $T_{a}$ and $R H$ were measured by a thermohygrometer (HMP45AC, Vaisala Inc., Woburn, MA, USA) installed $2 \mathrm{~m}$ above the ground level. $u$ was measured $10 \mathrm{~m}$ above the ground level using an anemometer (03101 R.M. Young Company, Traverse City, MI, USA). Precipitation was measured using a tipping bucket rainfall gauge (TR-525M, Texas Electronics, Inc., Dallas, TX, USA) installed $5 \mathrm{~m}$ above the ground level. We considered only data from days without gaps and measurement errors to avoid inconsistent information.

\subsection{Penman-Monteith Method and FAO Procedures When Climatic Data Are Missing}

The Penman-Monteith (FAO-PM) method (Equation (1)) is recommended by the Food and Agriculture Organization (FAO) as the standard method for determining reference 
evapotranspiration $\left(E T_{o}\right)$ [17]. We considered $E T_{o}$ computed with the full data set as the reference (benchmark) data for comparisons.

$$
E T_{o}=\frac{0.408 \Delta\left(R_{n}-G\right)+\gamma \frac{900}{\left(T_{a}+273\right)} u_{2}\left(e_{s}-e_{a}\right)}{\Delta+\gamma\left(1+0.34 u_{2}\right)}
$$

where $E T_{o}$ is the reference evapotranspiration $\left(\mathrm{mm} \cdot \mathrm{day}^{-1}\right), R_{n}$ is net radiation $\left(\mathrm{MJ} \cdot \mathrm{m}^{-2}\right.$.day ${ }^{-1}$ ), $G$ is the soil heat flux (MJ.m ${ }^{-2}$.day $\left.{ }^{-1}\right), T_{a}$ is the mean daily air temperature $\left({ }^{\circ} \mathrm{C}\right), u_{2}$ is the wind speed at $2 \mathrm{~m}$ height $\left(\mathrm{m} . \mathrm{s}^{-1}\right), e_{s}$ is the saturation water vapor pressure $(\mathrm{kPa}), e_{a}$ is the actual water vapor pressure $(\mathrm{kPa}), \gamma$ is the psychrometric constant $\left(\mathrm{kPA} .{ }^{\circ} \mathrm{C}^{-1}\right)$, and $\Delta$ is the slope of the water vapor pressure curve $\left(\mathrm{kPa} .{ }^{\circ} \mathrm{C}^{-1}\right)$. We used Equation (2) (Allen et al., 1998) to convert $u$ to $u_{2}$.

$$
u_{2}=u_{z} \frac{4.87}{\ln (67.8 z-5.42)}
$$

where $u_{z}$ is the measured wind speed at $z \mathrm{~m}$ above ground surface $\left(\mathrm{m} . \mathrm{s}^{-1}\right)$, and $z$ is the height of measurement above ground surface $(\mathrm{m})$, which is $10 \mathrm{~m}$ in our study.

To test the impact of radiation, relative humidity, and wind speed data, $E T_{0}$ was also calculated by the FAO-PM using estimated meteorological variables, $R_{s}, u_{2}$, and $e_{a}$, obtained by procedures given by Allen et al. [17] and compared with data collected through measurements.

The FAO recommends two different approaches to estimate $R_{s}$ when climatic data are missing, i.e., using temperature data or linear regression. In this study, we computed solar radiation by linear regression. $R_{S}$ was estimated using Equation (3).

$$
R_{s}=\left(a_{s}+b_{s} \frac{n}{N}\right) R_{a}
$$

where $R_{S}$ is the solar radiation (MJ.m ${ }^{-2}$.day ${ }^{-1}$ ), $n$ is the actual duration of sunshine (h), $N$ is the maximum possible duration of daylight hours (h), $R_{a}$ is the extraterrestrial radiation (MJ.m ${ }^{-2}$.day ${ }^{-1}$ ), and $a_{s}$ and $b_{s}$ are local regression constants. To estimate $R_{a}$, we used Equation (4).

$$
R_{a}=\frac{24(60)}{\pi} G_{s c} d_{r}\left[\omega_{s} \sin (\varphi) \sin (\delta)+\cos (\varphi) \cos (\delta) \sin \left(\omega_{s}\right)\right]
$$

where $R_{a}$ is the extraterrestrial radiation $\left(\mathrm{MJ} \cdot \mathrm{m}^{-2}\right.$.day $\left.{ }^{-1}\right), G_{s c}$ is the solar constant of $0.0820 \mathrm{MJ} . \mathrm{m}^{-2} \cdot \mathrm{min}^{-1}, d_{r}$ is the inverse relative Earth-Sun distance, $\omega_{s}$ is the sunset hour angle (rad), $\varphi$ is the latitude of the meteorological station ( $\mathrm{rad})$, and $\delta$ is the solar decimation (rad). The values of $d_{r}$ and $\delta$ were computed using Equations (5) and (6).

$$
\begin{gathered}
d_{r}=1+0.033 \cos \left(\frac{2 \pi}{365} J\right) \\
\delta=0.409 \sin \left(\frac{2 \pi}{365} J-1.39\right)
\end{gathered}
$$

where $J$ is the number of the day in the year between 1 (1 January) and 365 or 366 (31 December). $\omega_{s}$ was estimated using Equation (7).

$$
\omega_{s}=\cos ^{-1}[-\tan (\varphi) \tan (\delta)]
$$

$N$ was estimated using Equation (8).

$$
N=\frac{24}{\pi} \omega_{s}
$$


where $N$ is the maximum possible duration of daylight hours (h), and $\omega_{s}$ is the sunset hour angle (rad) computed by Equation (7).

An estimate of clear-sky solar radiation $\left(R_{s o}\right)$ (Equation (9)), net shortwave radiation $\left(R_{n s}\right)$ (Equation $\left.(10)\right)$, and net longwave radiation $\left(R_{n l}\right)$ is needed to estimate $R n$ from $R s$ (Equation (11)).

$$
R_{s o}=\left(a_{s}+b_{s}\right) R_{a}
$$

where $R_{s o}$ is the clear-sky radiation (MJ.m ${ }^{-2}$.day $\left.{ }^{-1}\right), a_{s}$ and $b_{s}$ are the parameters from Equation (3), and $R_{a}$ is the extraterrestrial radiation (MJ.m ${ }^{-2}$.day ${ }^{-1}$ ).

$$
R_{n s}=(1-\alpha) R_{s}
$$

where $R_{n s}$ is the net shortwave radiation $\left(\mathrm{MJ} \cdot \mathrm{m}^{-2}\right.$.day $\left.{ }^{-1}\right), \alpha$ is the albedo, which is 0.23 for the hypothetical grass reference crop, and $R_{s}$ is the solar radiation (MJ.m ${ }^{-2}$.day ${ }^{-1}$ )

$$
R_{n l}=\sigma\left(\frac{T_{\max , K^{4}+T_{\min , K} K^{4}}}{2}\right)\left(0.34-0.14 \sqrt{e_{a}}\right)\left(1.35 \frac{R_{s}}{R_{s o}}-0.35\right)
$$

where $R_{n l}$ is the net longwave radiation (MJ.m ${ }^{-2}$.day $\left.{ }^{-1}\right), \sigma$ is the Stefan-Boltzmann constant of $4.903 \times 10^{-9}$ MJ.K ${ }^{-4} . \mathrm{m}^{-2}$. day ${ }^{-1}, T_{\max , K}$ is the maximum absolute temperature during the $24 \mathrm{~h}$ period $(\mathrm{K}), T_{\min , K}$ is the minimum absolute temperature during the $24 \mathrm{~h}$ period $(\mathrm{K}), e_{a}$ is the actual vapor pressure $(\mathrm{kPa}), R_{s}$ is the solar radiation $\left(\mathrm{MJ} \cdot \mathrm{m}^{-2}\right.$.day $\left.{ }^{-1}\right)$, and $R_{s o}$ is the clear-sky radiation (MJ.m ${ }^{-2}$.day ${ }^{-1}$ ).

$R_{n}$ was estimated using Equation (12).

$$
R_{n}=R_{n s}-R_{n l}
$$

where $R_{n}$ is the net radiation $\left(\mathrm{MJ} \cdot \mathrm{m}^{-2}\right.$.day $\left.{ }^{-1}\right), R_{n s}$ is the net shortwave radiation $\left(\mathrm{MJ} \cdot \mathrm{m}^{-2}\right.$.day ${ }^{-1}$ ), and $R_{n l}$ is the net longwave radiation (MJ.m ${ }^{-2}$.day ${ }^{-1}$ ).

For locations for which there were no solar radiation data available or no calibration for improved estimates of $\mathrm{a}_{\mathrm{s}}$ and $\mathrm{b}_{\mathrm{s}}$, Allen et al. [17] recommend $a_{s}=0.25$ and $b_{s}=0.50$. We calibrated $a_{S}$ and $b_{s}$ values using observed $R_{s}$ values from April 2009 to March 2010. Using linear regression, the values of $a_{s}$ and $b_{s}$ were, respectively, 0.192 and $0.506\left(\mathrm{R}^{2}=0.833\right.$; $n=358$ observations). Estimations of $R_{s}$ were calculated using both the calibrated and recommended regression constants. Allen et al. [17] suggest considering daily $G \approx 0$.

$e_{a}$ was estimated using Equation (13), considering the absence of relative air humidity data.

$$
e_{a}=0.6108 e^{\left(\frac{17.27 T_{\min }}{T_{\min }+237.3}\right)}
$$

where $e_{a}$ is the actual water vapor pressure $(\mathrm{kPa})$, and $T_{\min }$ is the minimum temperature $\left({ }^{\circ} \mathrm{C}\right)$. Allen et al. [17] recommend the use of the dewpoint temperature; however, when humidity data are lacking, it can be assumed that the dewpoint temperature is near the daily minimum temperature.

For estimates of wind speed at $2 \mathrm{~m}$ height, Allen et al. [17] suggest the use of the average of wind speed from a nearby weather station over a several-day period. Therefore, $u_{2}$ was considered a constant value estimated using the daily mean value of wind speed during the period of measurements (April 2009 to August 2019).

\subsection{Hargreaves-Samani Method}

The Hargreaves-Samani method [22] is recommended by the FAO to compute $E T_{0}$, in mm.day ${ }^{-1}$, when only temperature data are available.

$$
E T_{o}=0.0023\left(T_{\text {mean }}+17.8\right) \sqrt{T_{\max }-T_{\min }} 0.408 R_{a}
$$

where $T_{\text {mean }}$ is the mean daily temperature $\left({ }^{\circ} \mathrm{C}\right), T_{\max }$ is the maximum daily temperature $\left({ }^{\circ} \mathrm{C}\right), T_{\min }$ is the minimum daily temperature $\left({ }^{\circ} \mathrm{C}\right)$, and $R_{a}$ is the extraterrestrial radiation 
(MJ.m ${ }^{-2} \cdot$ day $^{-1}$ ). The constant value of 0.408 is a conversion factor for MJ.m ${ }^{-2}$.day ${ }^{-1}$ to mm.day ${ }^{-1}$.

\section{5. $E T_{o}$ with Missing Climatic Data}

Table 1 summarizes the calculation of $E T_{o}$ from April 2010 to August 2019 using limited climatic data. We computed $E T_{o}$ with the following scenarios of estimated data: (a) solar radiation with calibrated parameters $\left(\mathrm{R}_{\mathrm{s}}-\mathrm{a}\right)$; (b) solar radiation with recommended parameters $\left(\mathrm{R}_{\mathrm{S}}-\mathrm{b}\right)$; (c) relative air humidity $(\mathrm{RH})$; (d) wind speed (WS); (e) $\mathrm{R}_{\mathrm{s}}$-a and $\mathrm{RH}$; (f) $\mathrm{R}_{\mathrm{s}}-\mathrm{b}$ and $\mathrm{RH}$; (g) $\mathrm{R}_{\mathrm{s}}$-a and WS; (h) $\mathrm{R}_{\mathrm{s}}-\mathrm{b}$ and WS; (i) RH and WS; (j) $\mathrm{R}_{\mathrm{s}}$-a, $\mathrm{RH}$, and WS; (k) $R_{s}-b, R H$, and WS, and (l) using the Hargreaves-Samani method (HS).

Table 1. Summary of $E T_{o}$ calculations with missing climatic data.

\begin{tabular}{|c|c|c|}
\hline Method & Symbol & Calculation of $E T_{o}$ \\
\hline $\begin{array}{c}\text { FAO-PM, no radiation data (using calibrated } \\
\text { parameters to estimate } R_{S} \text { ) }\end{array}$ & $\mathrm{R}_{\mathrm{s}}-\mathrm{a}$ & $E T_{o}\left(\right.$ Equation (1)); $R_{n}\left(\right.$ Equation (12)); $\mathrm{a}_{\mathrm{s}}$ and $\mathrm{b}_{\mathrm{s}}$ calibrated \\
\hline $\begin{array}{l}\text { FAO-PM, no radiation data (using } \\
\text { recommended parameters to estimate } R_{s} \text { ) }\end{array}$ & $\mathrm{R}_{\mathrm{s}}-\mathrm{b}$ & $E T_{o}$ (Equation (1)); $R_{n}$ (Equation (12)), $\mathrm{a}_{\mathrm{s}}$ and $\mathrm{b}_{\mathrm{s}}$ recommended \\
\hline FAO-PM, no relative air humidity data & $\mathrm{RH}$ & $E T_{o}($ Equation $(1)) ; e_{a}($ Equation $(13))$ \\
\hline FAO-PM. no wind speed data & WS & $E T_{o}$ (Equation (1)); $u_{2}$ calculated by daily mean wind speed \\
\hline Hargreaves-Samani & HS & $E T_{o}($ Equation (14)) \\
\hline
\end{tabular}

\subsection{Performance Evaluation}

We compared each $E T_{0}$ estimate with missing data against the FAO-PM benchmark $E T_{o}$ that was calculated without missing data. The comparisons were made by simple linear regression. The performance of each scenario was assessed using Willmott's index of agreement (d) [53] (Equation (15)), correlation coefficient (r) (Equation (16)), root mean square error (RMSE) in mm.day ${ }^{-1}$ (Equation (17)), and mean bias error (MBE) in mm.day ${ }^{-1}$ (Equation (18)).

$$
\begin{gathered}
d=1-\left[\frac{\sum_{i=1}^{n}\left(P_{i}-O_{i}\right)^{2}}{\sum_{i=1}^{n}\left(\left|P_{i}-\bar{O}\right|+\left|O_{i}-\bar{O}\right|\right)^{2}}\right] \\
r=\frac{\sum_{i=1}^{n}\left[\left(P_{i}-\bar{P}\right)\left(O_{i}-\bar{O}\right)\right]}{\sqrt{\left[\sum_{i=1}^{n}\left(P_{i}-\bar{P}\right)^{2}\right]\left[\sum_{i=1}^{n}\left(O_{i}-\bar{O}\right)^{2}\right]}} \\
\operatorname{RMSE}=\sqrt{\frac{\sum_{i=1}^{n}\left(O_{i}-P_{i}\right)^{2}}{n}} \\
\operatorname{MBE}=\frac{\sum_{i=1}^{n}\left(P_{i}-O_{i}\right)}{n}
\end{gathered}
$$

where $P_{i}$ is the estimate value of the $\mathrm{i}$-th day $\left(\mathrm{mm} \cdot \mathrm{day}^{-1}\right), O_{i}$ is the observed value of the

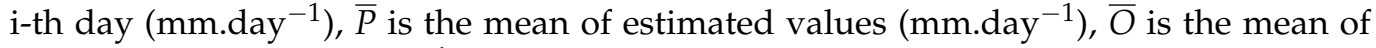
observed values $\left(\mathrm{mm}\right.$ day $\left.^{-1}\right)$, and $n$ is the number of observed values. Willmott's index of agreement (d) was used to quantify the degree of correspondence between $P_{i}$ and $O_{i}$, where $\mathrm{d}=1$ indicates complete correspondence and $\mathrm{d}=0$ indicates no correspondence between measured and modeled values [53]. The root mean square error (RMSE) was used to quantify the amount of error between the observed and estimated values [53].

\section{Results and Discussion}

\subsection{Seasonal Variation in Micrometeorological Condition}

The climate in the study area showed a distinct seasonal variation (Figure 2). The dry season, which was defined as the period with a rainfall depth lower than $100 \mathrm{~mm} / \mathrm{month}$ [4,54,55], occurred from April to October, and approximately $25 \%$ of the rainfall was 
recorded during this period (Figure $2 \mathrm{~F}$ ). Mean yearly accumulated rainfall ( \pm sd) was $941 \pm 297 \mathrm{~mm}$ during the study period, which is 34\% lower than the expected rainfall for this region.

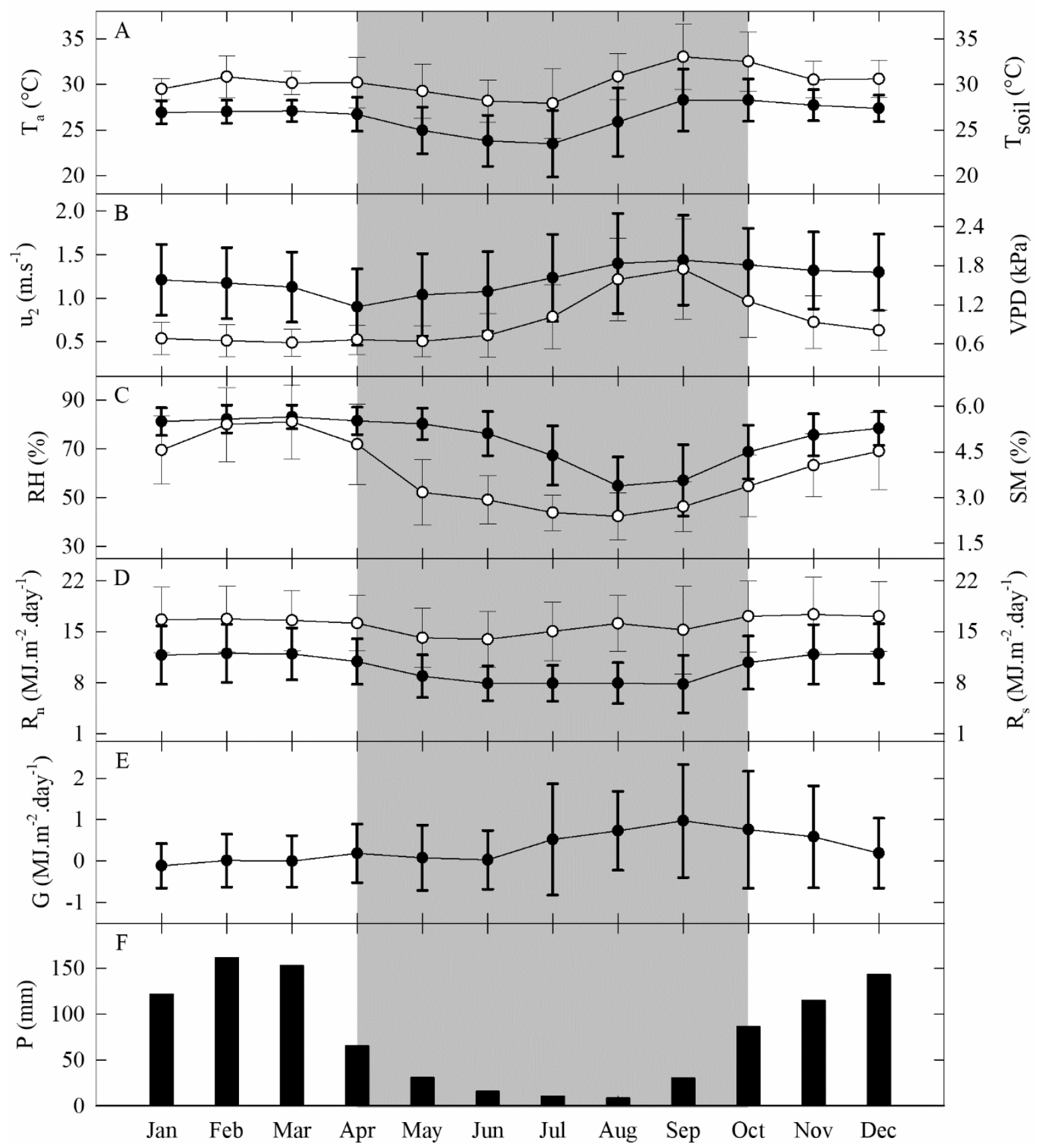

Figure 2. Mean monthly micrometeorological measurements of (A) air temperature (black circles, left-hand axis) and surface soil temperature (white circles, right-hand axis); (B) wind speed at $2 \mathrm{~m}$ height (black circles, left-hand axis) and vapor-pressure deficit (white circles, right-hand axis); (C) relative air humidity (black circles, left-hand axis) and surface soil moisture (white circles, right-hand axis); and (D) net radiation (black circles, left-hand axis) and solar radiation (white circles, right-hand axis); (E) soil heat flux; and (F) total monthly precipitation. The whiskers indicate the range within the standard deviation. The shadowed area indicates the dry season.

Variations in air and soil temperatures (Figure 2A) were higher during the dry season compared to the wet season, due to frequent cold fronts from the south [56]. The mean ( \pm sd) temperature during the study period was $26.4 \pm 2.9^{\circ} \mathrm{C}$. The month with the highest average air temperature was September $\left(28.3 \pm 3.4^{\circ} \mathrm{C}\right)$, while the month with the lowest 
air temperature was July $\left(23.5 \pm 3.7^{\circ} \mathrm{C}\right)$. The maximum air temperature was $42.0^{\circ} \mathrm{C}$, and the minimum was $6.3^{\circ} \mathrm{C}$. Relative humidity (Figure $2 \mathrm{C}$ ) also varied seasonally, with the highest average values observed during the wet season and the lowest observed during the dry season. Average monthly gravimetric soil moisture (mass water/mass dry soil) (Figure 2C) ranged between $4 \%$ and 5.5\% during the wet season, while soil water content reached $2.4 \%$ during the dry season when rainfall was scarce.

Wind speed at $2 \mathrm{~m}$ height (Figure 2B) showed a small seasonal variation during the study period, with an average value $( \pm \mathrm{sd})$ of $1.2 \pm 0.5 \mathrm{~m} . \mathrm{s}^{-1}$. We found relatively large daily variation, due to the sporadic nature of the wind in the study area [50]. Allen et al. [17] classified mean wind speed below $1 \mathrm{~m} \cdot \mathrm{s}^{-1}$ as light wind and wind speed between 1 and $3 \mathrm{~m} . \mathrm{s}^{-1}$ as light to moderate wind.

Net radiation (Figure 2D) was higher during the wet than the dry season; however, we found a larger standard deviation of $R_{n}$ in the wet season because of frequent cloud cover [57]. The dry-season decline in net radiation may be due to changes in vegetation and a decline of greenness during this season when soil moisture values were lower $[57,58]$. On the other hand, $\mathrm{R}_{\mathrm{s}}$ did not show a notable seasonal pattern like $R_{n}$ (Figure 2D).

Seasonal variations of soil heat flux are represented as $G$ (Figure 2E). Mean monthly values $( \pm \mathrm{sd})$ varied from $-0.11 \pm 0.54 \mathrm{MJ} . \mathrm{m}^{-2}$.day ${ }^{-1}$, in January, to $0.97 \pm 1.37 \mathrm{MJ} . \mathrm{m}^{-2}$.day ${ }^{-1}$, in September. From July to November, mean monthly and standard deviation values for $G$ were higher than 0.5 and $0.9 \mathrm{MJ} \cdot \mathrm{m}^{-2}$.day ${ }^{-1}$, respectively. During the dry season, vegetation leaf area declined due to the low soil water availability [58], causing an increase in uncovered area, and consequently, higher values of G. According to Rodrigues et al. [4], during September, $G$ accounts for about $30 \%$ of the energy balance of the campo sujo Cerrado. The contribution of $G$ in other tropical ecosystems, such as transition and tropical forests, accounts for about 1-2\% of the available energy due to the more closed canopy and greenness during the dry season [1], which is in contrast with our study area since its vegetation is sparse [50].

Figure 3 shows monthly mean $E T_{o}$ calculated using the Penman-Monteith method with observed meteorological data. The average $E T_{o}( \pm \mathrm{sd})$ was $3.49 \pm 1.13 \mathrm{~mm}$.day ${ }^{-1}$. Higher $E T_{o}$ values were observed during the wet season (November to March). When compared to the meteorological variables in Figure 2,ET estimates behaved similarly to $R_{n}$. Valle Júnior et al. [6] pointed out that $E T_{o}$ models based on $R_{n}$ perform better than different methods based on other variables for the campo sujo Cerrado conditions.

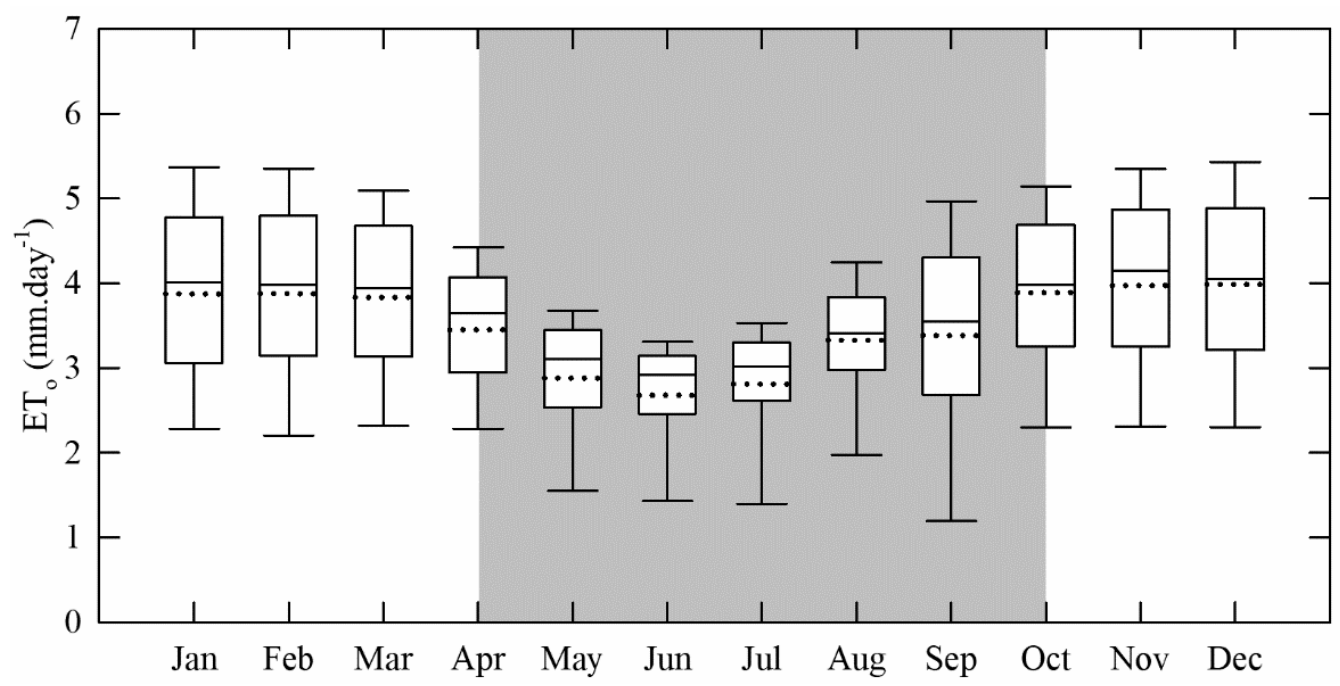

Figure 3. Boxplots showing daily $E T_{o}$ calculations for the Fazenda Miranda site. Each box lies between the second and third quartile, the central line is the median, and the dotted line is the monthly mean. The whiskers indicate the range of data within the minimum and maximum values. The shadowed area indicates the dry season. 


\subsection{ET $T_{0}$ Estimates with Limited Climatic Data}

For $E T_{0}$ values computed using limited meteorological data (Figure 4), the value for Willmott's d ranged between 0.64 and $0.99, \mathrm{r}$ between 0.68 and 0.98, RMSE between 0.21 and 1.56 , and absolute MBE values ranged from 0.01 to $1.29 \mathrm{~mm}^{-d a y}{ }^{-1}$, respectively (Table 2, Figure 5).
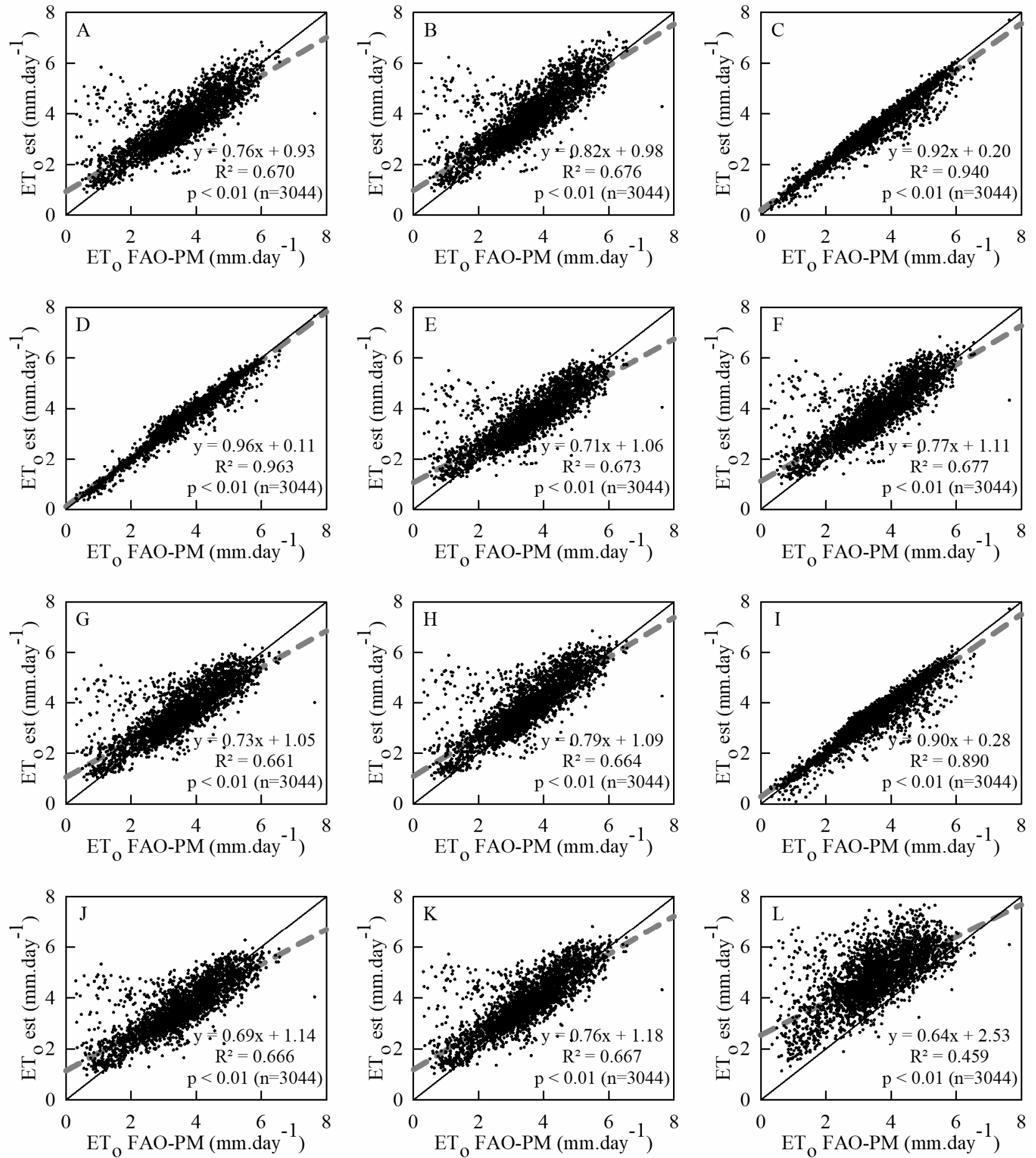

Figure 4. $\mathrm{ET}_{\mathrm{o}}$ values estimated using estimates of (A) Rs-a; (B) Rs-b; (C) RH; (D) WS; (E) Rs-a and RH; (F) Rs-b and RH; (G) Rs-a and WS; (H) Rs-b and WS; (I) RH and WS; J) Rs-a, RH, and WS; (K) Rs-b, RH, and WS; and (L) HS, in comparison with $E T_{0}$ estimated with full data set (ET FAO-PM). The central line represents a 1:1 correlation, and the dashed line represents the linear regression through the origin. 
Table 2. Comparison between $E T_{o}$ computed from full data set and estimates of $\mathrm{ET}_{\mathrm{o}}$ with missing climatic data.

\begin{tabular}{|c|c|c|c|c|}
\hline Method & d & $\mathbf{r}$ & $\begin{array}{c}\text { RMSE } \\
\left(\mathrm{mm}^{-d a y}{ }^{-1}\right)\end{array}$ & $\begin{array}{c}\text { MBE } \\
\left(\text { mm.day }^{-1}\right)\end{array}$ \\
\hline Rs-a & 0.90 & 0.82 & 0.66 & 0.10 \\
\hline Rs-b & 0.88 & 0.82 & 0.75 & 0.35 \\
\hline $\mathrm{RH}$ & 0.98 & 0.97 & 0.28 & -0.07 \\
\hline WS & 0.99 & 0.98 & 0.21 & -0.01 \\
\hline RS-a and RH & 0.90 & 0.82 & 0.64 & 0.05 \\
\hline RS-b and RH & 0.89 & 0.82 & 0.72 & 0.31 \\
\hline RS-a and WS & 0.90 & 0.81 & 0.66 & 0.09 \\
\hline RS-b and WS & 0.88 & 0.82 & 0.75 & 0.34 \\
\hline RH and WS & 0.97 & 0.94 & 0.37 & -0.06 \\
\hline RS-a, RH, and WS & 0.90 & 0.82 & 0.65 & 0.07 \\
\hline RS-b, RH, and WS & 0.88 & 0.82 & 0.73 & 0.33 \\
\hline HS & 0.64 & 0.68 & 1.56 & 1.29 \\
\hline
\end{tabular}
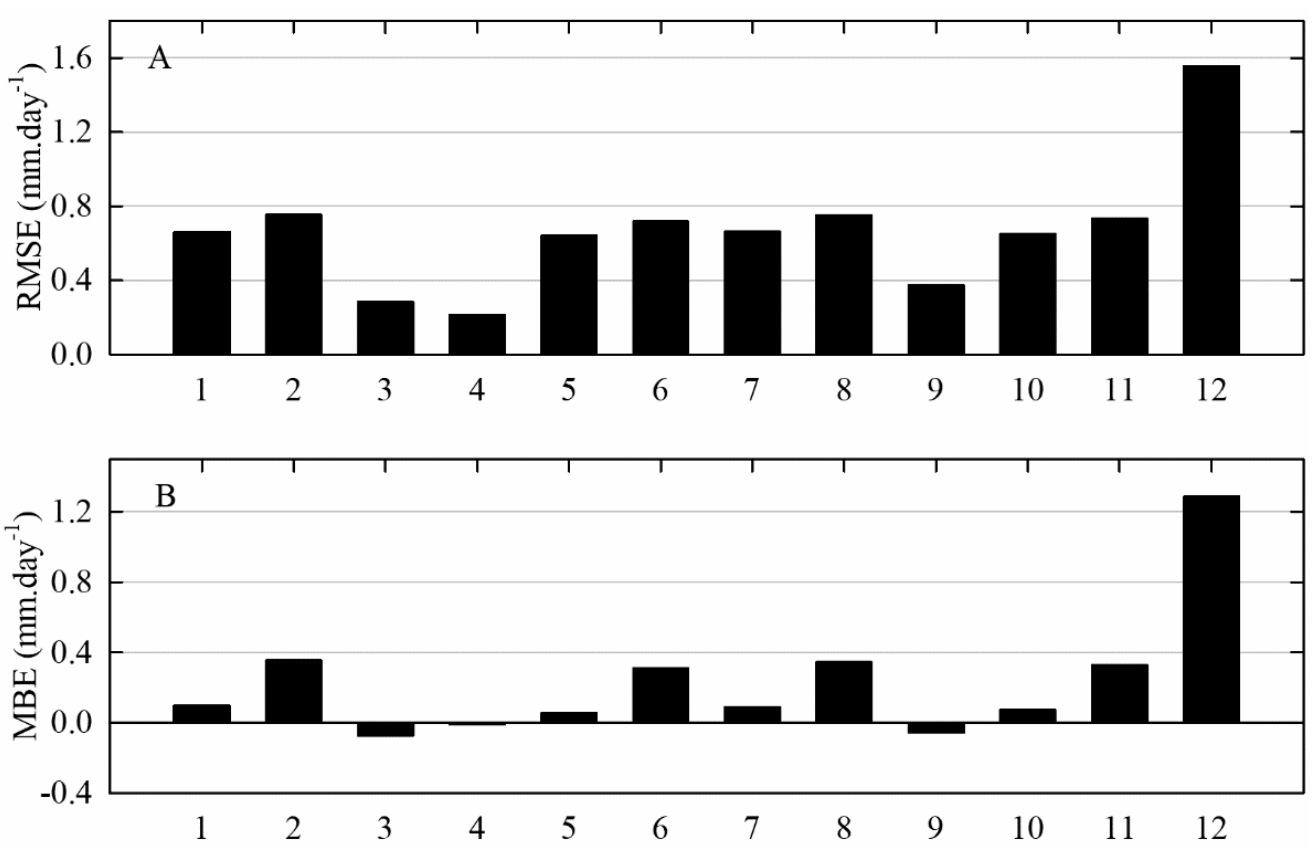

Figure 5. (A) Root mean square error (RMSE) and (B) mean bias error (MBE) of computed $E T_{o}$ using estimates of (1) Rs-a; (2) Rs-b; (3) RH; (4) WS; (5) Rs-a and RH; (6) Rs-b and RH; (7) Rs-a and WS; (8) Rs-b and WS; (9) RH and WS; (10) Rs-a, RH, and WS; (11) Rs-b, RH, and WS; and (12) HS.

The methods with relative humidity and/or wind speed as missing data (Figure 4C,D,I) showed better performance than the other methods, with high $\mathrm{r}$ and Willmott's $\mathrm{d}$ values that were close to 1.0 (Table 2), which indicate a perfect positive linear correlation and model performance. When using only average annual wind speed as estimated data, we obtained the lowest RMSE and the closest to zero MBE, with values of 0.21 and $-0.01 \mathrm{~mm} . \mathrm{day}^{-1}$, respectively. When relative humidity was the only missing climatic data, we obtained RMSE and MBE values of 0.28 and $-0.07 \mathrm{~mm}$.day ${ }^{-1}$, respectively. $E T_{o}$ estimates calculated when both relative humidity and wind speed data were missing had low RMSE and MBE values of 0.37 and $-0.06 \mathrm{~mm}^{- \text {day }^{-1}}$, which indicate that the estimations of $E T_{0}$ using observed $R_{s}$, $e_{a}$ computed from $T_{\min }$, and $\mathrm{u}_{2}$ from average values performed very well.

These findings were expected for missing humidity data since under humid conditions there is a high probability of $T_{\text {dew }}=T_{\min }$ [17]. Several locations presented similar results with $e_{a}$ estimated from minimum temperature [37,38,59]. Sentelhas et al. [60] reported $\mathrm{R}^{2}$ values from 0.76 to 0.96 when comparing $\mathrm{ET}_{\mathrm{o}}$ computed with actual vapor pressure to that 
computed from $T_{\min }$. This method may not be suitable to estimate $E T_{0}$ in humid climates since there are overestimations in VPD values [17,61].

Allen et al. [17] also suggest using a wind speed value of $2 \mathrm{~m} \cdot \mathrm{s}^{-1}$ when wind speed data are not available; however, $93 \%$ of data from measurements showed wind speed values below $2 \mathrm{~m} \cdot \mathrm{s}^{-1}$. Since wind speed for the Cerrado's conditions does not vary greatly throughout the year, it is possible to use a constant value of wind speed for estimating $E T_{0}$. Sun et al. [62] found similar results regarding the impact of wind speed on $E T_{o}$ in a mountainous region in China. Similar results were found by Popova et al. [38] and Córdova et al. [61], with the RMSE and MBE values near 0 when $u_{2}=2 \mathrm{~m} \cdot \mathrm{s}^{-1}$. Djaman et al. [59] presented unsuitable FAO-PM performances in dry conditions when wind speed was considered as $2 \mathrm{~m} . \mathrm{s}^{-1}$; however, using daily average wind speed in the same conditions, the results presented MBE values between -0.05 to 0.04 .

Our results indicate that wind speed and relative humidity and their variations throughout the year have a small effect on $E T_{o}$ estimates in the Cerrado region studied here. Investments in accurate air temperature sensors instead of investments in relative humidity probes would be a good option to estimate RH when the budget is limited. Moreover, use a constant value of $\mathbf{u}_{2}$ is also viable to estimate $E T_{0}$.

The methods without observed radiation data (Figure 4A,B,E-H,J,K) showed the lowest values of $\mathrm{r}$, i.e., the model results do not indicate a good linear correlation with reference data, when comparing $E T_{o}$ using FAO-PM method. However, when the benchmark values are close to the average $E T_{o}$ value, those results with estimated radiation were similar to $E T_{o}$ with full data. In addition, $E T_{o}$ computed with estimates of $R_{s}$ showed higher RMSE and $\mathrm{MBE}$ values than $E T_{o}$ computed when only wind speed and/or relative humidity were the missing variables. $E T_{0}$ calculated using radiation data computed with calibrated parameters were closer to the benchmark values than $E T_{o}$ calculated with $R_{S}$ estimates using regression constants recommended by Allen et al. [17].

When radiation values were missing, the resulting estimates of $E T_{0}$ consistently overestimated $E T_{o}$ when the benchmark values were low. Since the Penman-Monteith model (Equation (1)) uses $R_{n}-G$ as the radiation data input and Allen et al. [17] suggests $G \approx 0$ on a daily basis when there are no $G$ measurements, we compared $R_{n}$ estimates from Equation (12) with observed $R_{n}-G$ values. Similarly, we compared estimates of $e_{a}$ calculated when humidity data were lacking (Equation (3)) to measure $e_{a}$. Figure 6 presents the linear regression results, while Figure 7 shows RMSE and MBE values for the linear regressions of Figure 6 classified by seasons.

$R_{n}$ estimates were always $>0$ and overestimated net radiation values during the dry season when negative $R_{n}-G$ was observed (Figure $6 \mathrm{~A}-\mathrm{D}$ ). $R_{n}$ using the calibrated parameters presented lower absolute RMSE and MBE values, especially during the wet season (Figure 7A,B) when $R H$ had smaller daily variation (Figure $2 \mathrm{C}$ ) and errors in estimating $\mathrm{e}_{\mathrm{a}}$ were the lowest. $E T_{0}$ computed when radiation data was missing did not consider $G$, which was high in this Cerrado grassland; therefore, the suggestion by Allen et al. [17] to consider daily $G \approx 0$ is not suitable for our study area.

Our estimates of $E T_{o}$ when $R_{S}$ was missing were less accurate than those calculated with estimated wind speed and/or relative humidity, especially during the dry season when $R_{n}$ values are above the average. Different studies [63-65] observed good results for $R_{S}$ estimates using Equation (3); however, there is a lack of studies about solar radiation estimates in the Brazilian Cerrado. Other authors reported better performance of $E T_{o}$ calculated with estimated $R_{S}[36-38,61,66-68]$ than observed here, and $E T_{0}$ highly correlated with solar radiation in several different locations $[25,27,69,70]$. More research is needed to find a better model for estimating $R_{S}$ and $R_{n}$.

The daily $E T_{o}$ values computed from the Hargreaves-Samani model (Figure $4 \mathrm{~L}$ ) showed the worst correlation with the reference values. The RMSE and MBE values were 1.56 and $1.29 \mathrm{~mm} \cdot$ day $^{-1}$. Thus, while the Hargreaves-Samani equation was found to provide adequate estimates of $E T_{o}$ in a variety of climates, especially arid ones [39-41,71], it does not appear to be adequate for estimating $E T_{o}$ in the Cerrado. There are many different 
models to estimate $E T_{o}$; however, the FAO does not recommend any equation other than the Penman-Monteith and Hargreaves-Samani models.
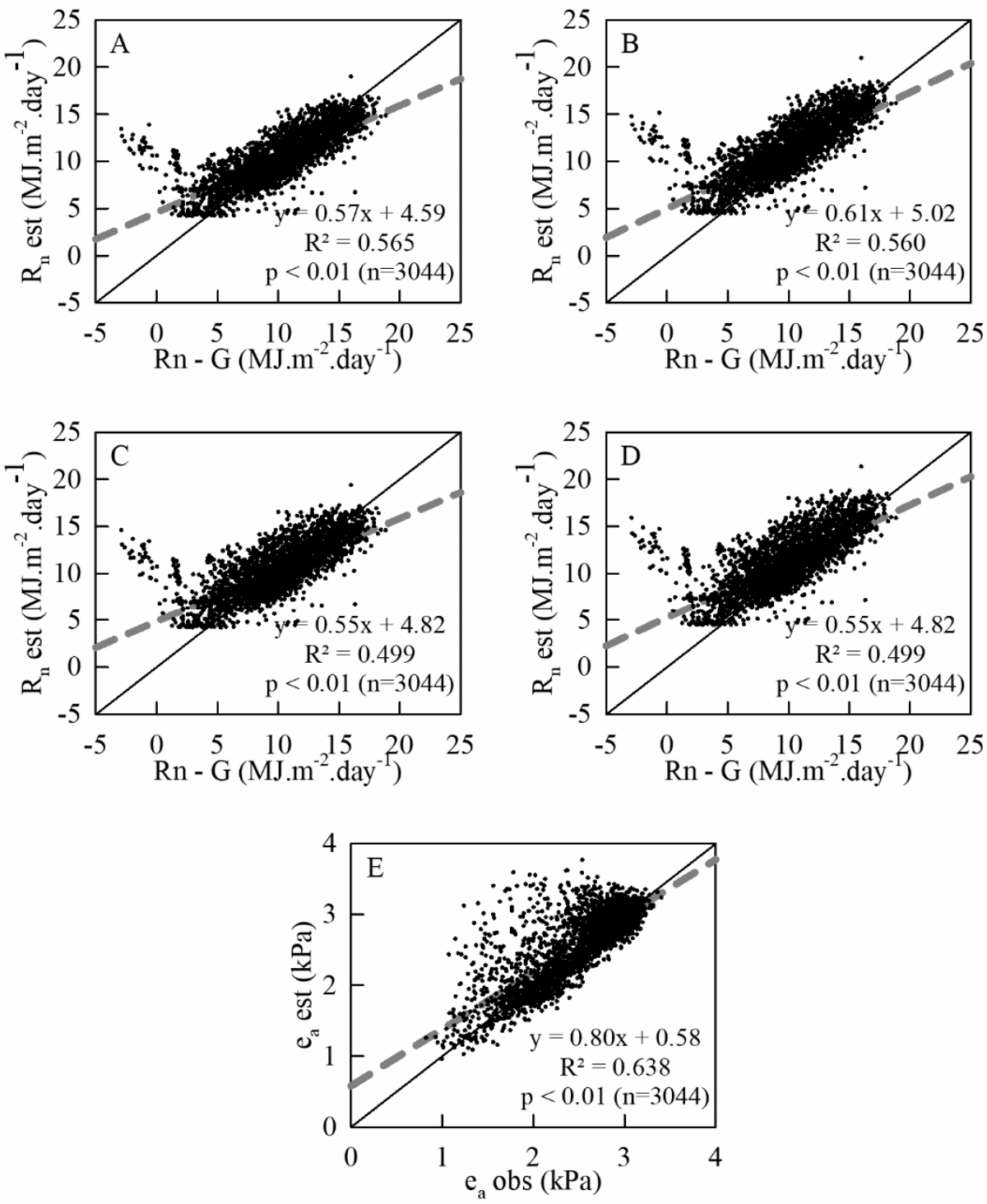

Figure 6. Linear regressions of (A) $R_{n}$ estimates using calibrated parameters and real $e_{a} ;(\mathbf{B}) R_{n}$ estimates using recommended parameters and real $e_{a} ;(\mathrm{C}) R n$ estimates using calibrated parameters and estimated $e_{a}$; and (D) $R_{n}$ estimates using recommended parameters and estimated $e_{a}$, in comparison with real values of $R_{n}-G$; and (E) a linear regression of estimated $e_{a}$ versus observed values. The central line represents a 1:1 correlation and the dashed line represents the linear regression through the origin.

However, the quality control of the dataset utilized for $E T_{0}$ computation with the FAO-PM or the HS equation is vital for the precision of estimates. Therefore, quality control of site and weather datasets is certainly needed, as it is essential to the appraisal of the quality of satellite-based and reanalysis datasets when applied to compute FAO-PM. Future studies along this line are needed. The data-driven model in this vital agricultural region can also be used for estimating $E T_{0}$ in future studies. The outcome obtained from our study can be seasonal-climate sensitive. This also deserves further examination. The main implication of this study is that the availability of precise models and datasets for quantifying $E T_{o}$ is significant for agricultural managers and irrigation engineers in a region with a similar climatic condition. In addition, it is important to explore different solar and net radiation models, since the guidelines provided by the FAO are not suitable for similar 
climatic conditions as our study area. Although investigating those alternatives is out of scope in the present study, they deserve further examination.
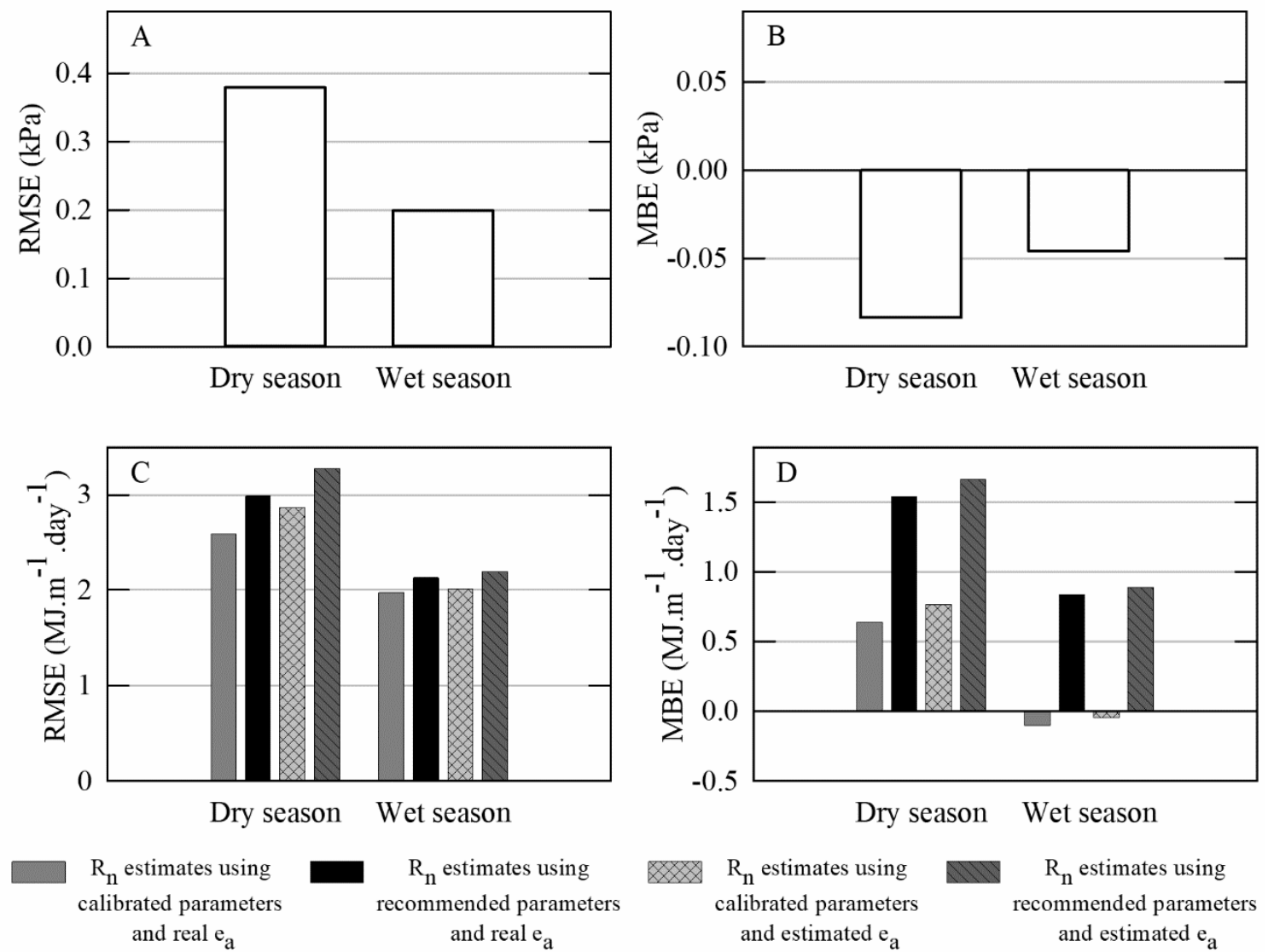

Figure 7. (A) Root mean square error (RMSE) and (B) mean bias error (MBE) of estimated $e_{a}$ versus real $e_{a}$; and (C) root mean square error (RMSE) and (D) mean bias error (MBE) of estimated $R_{n}$ in comparison with measured $R_{n}-G$. The legend of colors and patterns is the same for both graphs (C,D).

\section{Conclusions}

The overarching goal of our study was to evaluate the Penman-Monteith method's performance in a grass-dominated part of the Cerrado when climatic data are limited. We used $E T_{o}$ computed with a full data set of micrometeorological measurements as the reference data and tested the Penman-Monteith method when data for radiation, wind speed, and relative air humidity were missing.

We found better results for $E T_{0}$ calculated with estimated relative humidity and wind speed. Using average annual wind speed showed excellent results, with an almost perfect linear correlation and the lowest errors. The use of $T_{\text {dew }}=T_{\min }$ proved to be a great alternative to estimate $E T_{o}$ when RH data are missing, especially during the wet season.

$E T_{0}$ computed with solar radiation estimates performed worse than estimates when the other variables are missing. $R_{n}$ estimates could not compute negative values and $G$ $\approx 0$ may not be appropriate for the campo sujo Cerrado conditions. $E T_{0}$ estimates were not suitable when solar radiation data were missing. The Hargreaves-Samani method consistently overestimated $E T_{o}$ and did not perform well compared to the other methods.

The results presented here can help us better understand which meteorological data have the largest impact on $E T_{0}$ estimates of regions with similar climate and vegetation characteristics. Since the Cerrado is the main agricultural region in Brazil, our results could lead to new studies regarding algorithms and alternatives to estimate solar and net radiation in similar weather conditions. Improvements and investments in solar radiation 
measurements would provide more adequate $E T_{o}$ estimates and a better understanding of crop water demands.

Author Contributions: L.C.G.d.V.J. and T.R.R. analyzed the data and wrote the paper. L.F.A.C., R.d.S.P., J.d.S.N., and F.d.A.L. provided the data and interpreted the results. G.L.V. and A.R.M.T.I. reviewed the paper. All co-authors contributed significantly to this paper. All authors have read and agreed to the published version of the manuscript.

Funding: This research was supported by the Conselho Nacional de Desenvolvimento Científico e Tecnológico (CNPq) through the Bolsa de Produtividade em Pesquisa-PQ (grant number 308844/20181) and by the Coordenação de Aperfeiçoamento de Pessoal de Nivel Superior (CAPES) with Ph.D. scholarships.

Institutional Review Board Statement: Not applicable.

Informed Consent Statement: Not applicable.

Data Availability Statement: Data will be available upon request from the corresponding author.

Acknowledgments: This research was supported by the Universidade Federal de Mato Grosso do Sul (UFMS), the Programa de Pós-Graduação em Tecnologias Ambientais (PPGTA), the Conselho Nacional de Desenvolvimento Científico e Tecnológico (CNPq) through the Bolsa de Produtividade em Pesquisa-PQ (Grant Number 308844/2018-1), and the Coordenação de Aperfeiçoamento de Pessoal de Nivel Superior (CAPES) with Ph.D. scholarships. We thank Instituto Nacional de Meteorologia (INMET) for providing data and maintaining the Padre Ricardo Remetter meteorological station. We also acknowledge Programa Pós-Graduação de Física Ambiental (PPGFA) and the Universidade Federal de Mato Grosso (UFMT) for providing data, and their professors for data collection. The authors are grateful to Clovis Miranda and his family for allowing this study to be developed at the Fazenda Miranda.

Conflicts of Interest: The authors declare that they have no known competing financial interests or personal relationships that could have appeared to influence the work reported in this paper.

\section{References}

1. Giambelluca, T.W.; Scholz, F.G.; Bucci, S.J.; Meinzer, F.C.; Goldstein, G.; Hoffmann, W.A.; Franco, A.C.; Buchert, M.P. Evapotranspiration and energy balance of Brazilian savannas with contrasting tree density. Agric. For. Meteorol. 2009, 149, $1365-1376$. [CrossRef]

2. Nóbrega, R.L.B.; Guzha, A.C.; Lamparter, G.; Amorim, R.S.S.; Couto, E.G.; Hughes, H.J.; Jungkunst, H.F.; Gerold, G. Impacts of land-use and land-cover change on stream hydrochemistry in the Cerrado and Amazon biomes. Sci. Total Environ. 2018, 635, 259-274. [CrossRef] [PubMed]

3. Oliveira, P.T.S.; Nearing, M.A.; Moran, M.S.; Goodrich, D.C.; Wendland, E.; Gupta, H.V. Trends in water balance components across the Brazilian Cerrado. Water Resour. Res. 2014, 50, 7100-7114. [CrossRef]

4. Rodrigues, T.R.; Vourlitis, G.L.; Lobo, F.D.A.; de Oliveira, R.G.; Nogueira, J.D.S. Seasonal variation in energy balance and canopy conductance for a tropical savanna ecosystem of south central Mato Grosso, Brazil. J. Geophys. Res. Biogeosci. 2014, $119,1-13$. [CrossRef]

5. Silva, J.B.; Gaio, D.C.; Curado, L.F.A.; Nogueira, J.D.S.; Valle Júnior, L.C.G.; Rodrigues, T.R. Evaluation of methods for estimating atmospheric emissivity in Mato-Grossense Cerrado. Ambient. Agua Interdiscip. J. Appl. Sci. 2019, 14, 1. [CrossRef]

6. Valle Júnior, L.C.G.; Ventura, T.M.; Gomes, R.S.R.; de Nogueira, J.S.; de Lobo, F.A.; Vourlitis, G.L.; Rodrigues, T.R. Comparative assessment of modelled and empirical reference evapotranspiration methods for a brazilian savanna. Agric. Water Manag. 2020, 232, 106040. [CrossRef]

7. Doorenbos, J.; Pruitt, W.O. Guidelines for Predicting Crop Water Requirements; FAO Irrigation and Drainage Paper no.24; FAO: Rome, Italy, 1977; ISBN 92-5-100279-7.

8. Allen, R.G. Assessing Integrity of Weather Data for Reference Evapotranspiration Estimation. J. Irrig. Drain. Eng. 1996, 122, 97-106. [CrossRef]

9. Dong, Q.; Wang, W.; Shao, Q.; Xing, W.; Ding, Y.; Fu, J. The response of reference evapotranspiration to climate change in Xinjiang, China: Historical changes, driving forces, and future projections. Int. J. Climatol. 2020, 40, 235-254. [CrossRef]

10. Droogers, P.; Allen, R.G. Estimating reference evapotranspiration under inaccurate data conditions. Irrig. Drain. Syst. 2002, 16, 33-45. [CrossRef]

11. Hargreaves, G.H. Defining and Using Reference Evapotranspiration. J. Irrig. Drain. Eng. 1994, 120, 1132-1139. [CrossRef]

12. She, D.; Xia, J.; Zhang, Y. Changes in reference evapotranspiration and its driving factors in the middle reaches of Yellow River Basin, China. Sci. Total Environ. 2017, 607-608, 1151-1162. [CrossRef] 
13. Tyagi, N.; Sharma, D.; Luthra, S. Determination of evapotranspiration and crop coefficients of rice and sunflower with lysimeter. Agric. Water Manag. 2000, 45, 41-54. [CrossRef]

14. Allen, R.G.; Smith, M.; Pereira, L.S.; Perrier, A. An Update for the Calculation of Reference Evapotranspiration. ICID Bull. 1994, $43,35-92$.

15. Martins, D.S.; Paredes, P.; Raziei, T.; Pires, C.; Cadima, J.; Pereira, L.S. Assessing reference evapotranspiration estimation from reanalysis weather products. An application to the Iberian Peninsula. Int. J. Climatol. 2017, 37, 2378-2397. [CrossRef]

16. Sharifi, A.; Dinpashoh, Y. Sensitivity Analysis of the Penman-Monteith reference Crop Evapotranspiration to Climatic Variables in Iran. Water Resour. Manag. 2014, 28, 5465-5476. [CrossRef]

17. Allen, R.G.; Pereira, L.S.; Raes, D.; Smith, M. Crop Evapotranspiration: Guidelines for Computing Crop Water Requirements; FAO Irrigation and Drainage Paper no. 56; FAO: Rome, Italy, 1998; ISBN 92-5-104219-5.

18. Xu, C.; Gong, L.; Jiang, T.; Chen, D.; Singh, V.P. Analysis of spatial distribution and temporal trend of reference evapotranspiration and pan evaporation in Changjiang (Yangtze River) catchment. J. Hydrol. 2006, 327, 81-93. [CrossRef]

19. Almorox, J.; Grieser, J. Calibration of the Hargreaves-Samani method for the calculation of reference evapotranspiration in different Köppen climate classes. Hydrol. Res. 2016, 47, 521-531. [CrossRef]

20. Srivastava, A.; Sahoo, B.; Raghuwanshi, N.S.; Singh, R. Evaluation of Variable-Infiltration Capacity Model and MODIS-Terra Satellite-Derived Grid-Scale Evapotranspiration Estimates in a River Basin with Tropical Monsoon-Type Climatology. J. Irrig. Drain. Eng. 2017, 143, 04017028. [CrossRef]

21. Blaney, H.F.; Criddle, W.D. Determining Water Requirements in Irrigated Areas from Climatological and Irrigation Data; United States Department of Agriculture: Washington, DC, USA, 1950.

22. Hargreaves, G.H.; Samani, Z.A. Reference Crop Evapotranspiration from Temperature. Appl. Eng. Agric. 1985, 1, 96-99. [CrossRef]

23. Jensen, M.E.; Haise, H.R. Estimating evapotranspiration from solar radiation. J. Irrig. Drain. 1963, 4, 15-41. [CrossRef]

24. Priestley, C.H.B.; Taylor, R.J. On the Assessment of Surface Heat Flux and Evaporation Using Large-Scale Parameters. Mon. Weather Rev. 1972, 100, 81-92. [CrossRef]

25. Bourletsikas, A.; Argyrokastritis, I.; Proutsos, N. Comparative evaluation of 24 reference evapotranspiration equations applied on an evergreen-broadleaved forest. Hydrol. Res. 2017, nh2017232. [CrossRef]

26. Shafieiyoun, E.; Gheysari, M.; Khiadani, M.; Koupai, J.A.; Shojaei, P.; Moomkesh, M. Assessment of reference evapotranspiration across an arid urban environment having poor data monitoring system. Hydrol. Process. 2020, 34, 4000-4016. [CrossRef]

27. Shiri, J. Modeling reference evapotranspiration in island environments: Assessing the practical implications. J. Hydrol. 2019, 570, 265-280. [CrossRef]

28. Tabari, H.; Grismer, M.E.; Trajkovic, S. Comparative analysis of 31 reference evapotranspiration methods under humid conditions. Irrig. Sci. 2013, 31, 107-117. [CrossRef]

29. Zhang, Q.; Cui, N.; Feng, Y.; Gong, D.; Hu, X. Improvement of Makkink model for reference evapotranspiration estimation using temperature data in Northwest China. J. Hydrol. 2018, 566, 264-273. [CrossRef]

30. Dinpashoh, Y.; Jhajharia, D.; Fakheri-Fard, A.; Singh, V.P.; Kahya, E. Trends in reference crop evapotranspiration over Iran. J. Hydrol. 2011, 399, 422-433. [CrossRef]

31. Gong, L.; Xu, C.; Chen, D.; Halldin, S.; Chen, Y.D. Sensitivity of the Penman-Monteith reference evapotranspiration to key climatic variables in the Changjiang (Yangtze River) basin. J. Hydrol. 2006, 329, 620-629. [CrossRef]

32. Srivastava, A.; Sahoo, B.; Raghuwanshi, N.S.; Chatterjee, C. Modelling the dynamics of evapotranspiration using Variable Infiltration Capacity model and regionally calibrated Hargreaves approach. Irrig. Sci. 2018, 36, 289-300. [CrossRef]

33. Kumari, N.; Srivastava, A. An Approach for Estimation of Evapotranspiration by Standardizing Parsimonious Method. Agric. Res. 2020, 9, 301-309. [CrossRef]

34. Oudin, L.; Hervieu, F.; Michel, C.; Perrin, C.; Andréassian, V.; Anctil, F.; Loumagne, C. Which potential evapotranspiration input for a lumped rainfall-runoff model? Part 2-Towards a simple and efficient potential evapotranspiration model for rainfall-runoff modelling. J. Hydrol. 2005, 303, 290-306. [CrossRef]

35. Čadro, S.; Uzunović, M.; Žurovec, J.; Žurovec, O. Validation and calibration of various reference evapotranspiration alternative methods under the climate conditions of Bosnia and Herzegovina. Int. Soil Water Conserv. Res. 2017, 5, 309-324. [CrossRef]

36. Djaman, K.; Irmak, S.; Asce, M.; Futakuchi, K. Daily Reference Evapotranspiration Estimation under Limited Data in Eastern Africa. J. Irrig. Drain. Eng. 2016, 1-13. [CrossRef]

37. Jabloun, M.; Sahli, A. Evaluation of FAO-56 methodology for estimating reference evapotranspiration using limited climatic data. Application to Tunisia. Agric. Water Manag. 2008, 95, 707-715. [CrossRef]

38. Popova, Z.; Kercheva, M.; Pereira, L.S. Validation of the FAO methodology for computing ETo with limited data. Application to south Bulgaria. Irrig. Drain. 2006, 55, 201-215. [CrossRef]

39. Raziei, T.; Pereira, L.S. Spatial variability analysis of reference evapotranspiration in Iran utilizing fine resolution gridded datasets. Agric. Water Manag. 2013, 126, 104-118. [CrossRef]

40. Raziei, T.; Pereira, L.S. Estimation of ETo with Hargreaves-Samani and FAO-PM temperature methods for a wide range of climates in Iran. Agric. Water Manag. 2013, 121, 1-18. [CrossRef]

41. Todorovic, M.; Karic, B.; Pereira, L.S. Reference evapotranspiration estimate with limited weather data across a range of Mediterranean climates. J. Hydrol. 2013, 481, 166-176. [CrossRef] 
42. Ferreira, L.B.; da Cunha, F.F.; de Oliveira, R.A.; Fernandes Filho, E.I. Estimation of reference evapotranspiration in Brazil with limited meteorological data using ANN and SVM-A new approach. J. Hydrol. 2019, 572, 556-570. [CrossRef]

43. Karimi, S.; Kisi, O.; Kim, S.; Nazemi, A.H.; Shiri, J. Modelling daily reference evapotranspiration in humid locations of South Korea using local and cross-station data management scenarios. Int. J. Climatol. 2017, 37, 3238-3246. [CrossRef]

44. Mattar, M.A. Using gene expression programming in monthly reference evapotranspiration modeling: A case study in Egypt. Agric. Water Manag. 2018, 198, 28-38. [CrossRef]

45. Mehdizadeh, S.; Behmanesh, J.; Khalili, K. Using MARS, SVM, GEP and empirical equations for estimation of monthly mean reference evapotranspiration. Comput. Electron. Agric. 2017, 139, 103-114. [CrossRef]

46. Salam, R.; Islam, A.R.M.T. Potential of RT, bagging and RS ensemble learning algorithms for reference evapotranspiration prediction using climatic data-limited humid region in Bangladesh. J. Hydrol. 2020, 590, 125241. [CrossRef]

47. Kisi, O. Pan evaporation modeling using least square support vector machine, multivariate adaptive regression splines and M5 model tree. J. Hydrol. 2015, 528, 312-320. [CrossRef]

48. Wang, L.; Kisi, O.; Hu, B.; Bilal, M.; Zounemat-Kermani, M.; Li, H. Evaporation modelling using different machine learning techniques. Int. J. Climatol. 2017, 37, 1076-1092. [CrossRef]

49. Wang, L.; Kisi, O.; Zounemat-Kermani, M.; Li, H. Pan evaporation modeling using six different heuristic computing methods in different climates of China. J. Hydrol. 2017, 544, 407-427. [CrossRef]

50. Rodrigues, T.R.; Vourlitis, G.L.; de Lobo, F.A.; Santanna, F.B.; de Arruda, P.H.Z.; de Nogueira, J.S. Modeling canopy conductance under contrasting seasonal conditions for a tropical savanna ecosystem of south central Mato Grosso, Brazil. Agric. For. Meteorol. 2016, 218, 218-219-229. [CrossRef]

51. Alvares, C.A.; Stape, J.L.; Sentelhas, P.C.; de Moraes Gonçalves, J.L.; Sparovek, G. Köppen's climate classification map for Brazil. Meteorol. Z. 2013, 22, 711-728. [CrossRef]

52. Vourlitis, G.L.; da Rocha, H.R. Flux Dynamics in the Cerrado and Cerrado-Forest Transition of Brazil. In Ecosystem Function in Global Savannas: Measurement and Modeling at Landscape to Global Scales; Hill, M.J., Hanan, N.P., Eds.; CRC, Inc.: Boca Raton, FL, USA, 2011; pp. 97-116.

53. Willmott, C.J. Some Comments on the Evaluation of Model Performance. Bull. Am. Meteorol. Soc. 1982, 63, 1309-1313. [CrossRef]

54. Hutyra, L.R.; Munger, J.W.; Nobre, C.A.; Saleska, S.R.; Vieira, S.A.; Wofsy, S.C. Climatic variability and vegetation vulnerability in Amazônia. Geophys. Res. Lett. 2005, 32, L24712. [CrossRef]

55. Rodrigues, T.R.; Curado, L.F.A.; Pereira, V.M.R.; Sanches, L.; Nogueira, J.S. Hourly interaction between wind speed and energy fluxes in Brazilian wetlands-Mato Grosso-Brazil. An. Acad. Bras. Cienc. 2016, 88, 2195-2209. [CrossRef] [PubMed]

56. Grace, J.; Malhi, Y.; Lloyd, J.; McIntyre, J.; Miranda, A.C.; Meir, P.; Miranda, H.S. The use of eddy covariance to infer the net carbon dioxide uptake of Brazilian rain forest. Glob. Chang. Biol. 1996, 2, 209-217. [CrossRef]

57. Machado, L.A.T.; Laurent, H.; Dessay, N.; Miranda, I. Seasonal and diurnal variability of convection over the Amazonia: A comparison of different vegetation types and large scale forcing. Theor. Appl. Climatol. 2004, 78, 61-77. [CrossRef]

58. Rodrigues, T.R.; de Paulo, S.R.; Novais, J.W.Z.; Curado, L.F.; Nogueira, J.S.; de Oliveira, R.G.; Lobo, F.D.; Vourlitis, G.L. Temporal Patterns of Energy Balance for a Brazilian Tropical Savanna under Contrasting Seasonal Conditions. Int. J. Atmos. Sci. 2013, 2013, 1-9. [CrossRef]

59. Djaman, K.; Irmak, S.; Kabenge, I.; Futakuchi, K. Evaluation of FAO-56 Penman-Monteith Model with Limited Data and the Valiantzas Models for Estimating Grass-Reference Evapotranspiration in Sahelian Conditions. J. Irrig. Drain. Eng. 2016, 142, 04016044. [CrossRef]

60. Sentelhas, P.C.; Gillespie, T.J.; Santos, E.A. Evaluation of FAO Penman-Monteith and alternative methods for estimating reference evapotranspiration with missing data in Southern Ontario, Canada. Agric. Water Manag. 2010, 97, 635-644. [CrossRef]

61. Córdova, M.; Carrillo-Rojas, G.; Crespo, P.; Wilcox, B.; Célleri, R. Evaluation of the Penman-Monteith (FAO 56 PM) Method for Calculating Reference Evapotranspiration Using Limited Data. Mt. Res. Dev. 2015, 35, 230-239. [CrossRef]

62. Sun, J.; Wang, G.; Sun, X.; Lin, S.; Hu, Z.; Huang, K. Elevation-dependent changes in reference evapotranspiration due to climate change. Hydrol. Process. 2020, 34, 5580-5594. [CrossRef]

63. Aladenola, O.O.; Madramootoo, C.A. Evaluation of solar radiation estimation methods for reference evapotranspiration estimation in Canada. Theor. Appl. Climatol. 2014, 118, 377-385. [CrossRef]

64. Jahani, B.; Dinpashoh, Y.; Raisi Nafchi, A. Evaluation and development of empirical models for estimating daily solar radiation. Renew. Sustain. Energy Rev. 2017, 73, 878-891. [CrossRef]

65. Trnka, M.; Žalud, Z.; Eitzinger, J.; Dubrovský, M. Global solar radiation in Central European lowlands estimated by various empirical formulae. Agric. For. Meteorol. 2005, 131, 54-76. [CrossRef]

66. Cai, J.; Liu, Y.; Lei, T.; Pereira, L.S. Estimating reference evapotranspiration with the FAO Penman-Monteith equation using daily weather forecast messages. Agric. For. Meteorol. 2007, 145, 22-35. [CrossRef]

67. Paredes, P.; Martins, D.S.; Pereira, L.S.; Cadima, J.; Pires, C. Accuracy of daily estimation of grass reference evapotranspiration using ERA-Interim reanalysis products with assessment of alternative bias correction schemes. Agric. Water Manag. 2018, 210, 340-353. [CrossRef]

68. Salam, R.; Islam, A.R.M.T.; Pham, Q.B.; Dehghani, M.; Al-Ansari, N.; Linh, N.T.T. The optimal alternative for quantifying reference evapotranspiration in climatic sub-regions of Bangladesh. Sci. Rep. 2020, 10, 20171. [CrossRef] 
69. de Oliveira, R.G.; Valle Júnior, L.C.G.; da Silva, J.B.; Espíndola, D.A.L.F.; Lopes, R.D.; Nogueira, J.S.; Curado, L.F.A.; Rodrigues, T.R. Temporal trend changes in reference evapotranspiration contrasting different land uses in southern Amazon basin. Agric. Water Manag. 2021, 250, 106815. [CrossRef]

70. Jhajharia, D.; Dinpashoh, Y.; Kahya, E.; Singh, V.P.; Fakheri-Fard, A. Trends in reference evapotranspiration in the humid region of northeast India. Hydrol. Process. 2012, 26, 421-435. [CrossRef]

71. Almorox, J.; Senatore, A.; Quej, V.H.; Mendicino, G. Worldwide assessment of the Penman-Monteith temperature approach for the estimation of monthly reference evapotranspiration. Theor. Appl. Climatol. 2018, 131, 693-703. [CrossRef] 